\title{
Influence of brine treatment,drying methods and storage conditions on the microbial quality of freshwater snail (Lanistes libycus) meat.
}

\author{
Ezeama, C. F. ${ }^{* 1}$, Keke, E. ${ }^{3}$ and Nwachukwu, E. ${ }^{2}$ \\ ${ }^{1}$ Department of Food Science and Technology, ${ }^{2}$ Department of Microbiology, \\ Michael Okpara University of Agriculture, Umudike, P.M.B. 7267 Umuahia, Abia State, Nigeria. \\ ${ }^{3}$ Department of Science Laboratory Technology, Akanu Ibiam Federal Polytechnic, Unwana, \\ Ebonyi state, Nigeria. \\ *Address for correspondence, E-mail: cfezeama@yahoo.com
}

ABSTRACT

\begin{abstract}
Freshwater snail (Lanistes libycus) meat samples were subjected to four different preservation treatments (ovendried, sun-dried, brined oven-dried, brined sun-dried) and assessed for microbiological quality. The microbial quality of fresh or brine $(5 \% \mathrm{w} / \mathrm{v} \mathrm{NaCl})$ treated samples stored at different temperatures $\left(35,28,4,-7{ }^{\circ} \mathrm{C}\right)$ were also investigated. Combining brine treatment with either ovendrying or sun-drying resulted in significant $(\mathrm{p}=0.05)$ decrease in total viable counts (TVCs) of the meat with that of brined oven-dried samples being more pronounced $\left(\log _{10} 3.92 \mathrm{cfu} \mathrm{g}^{-1}\right)$ by day 4 of ambient storage. Sun-drying alone could not effectively preserve the meat beyond 2
\end{abstract}

\section{INTRODUCTION}

$\mathrm{T}$ The freshwater snail (Lanistes libycus) is a popular, seasonal freshwater food widely distributed in Nigeria especially in the Niger Delta and Upper Cross River basins (Arene et al., 1999; Obureke etal., 1987). It serves as a major source of protein as well as generating income to the people (Ezeama, 2000). The spoilage of (L. libycus) sets in after about $48 \mathrm{~h}$ of harvest while shucking accelerates the spoilage rate as the meat cannot be kept in acceptable condition after approximately $12 \mathrm{~h}$. Hence, the preservation of the meat has become days. No significant difference $(\mathrm{p}=0.05)$ existed in the microbial loads of oven-dried and brined sun-dried samples stored at ambient temperature. The TVCs of all traditionally dried samples were microbiologically unacceptable $\left(>\left(\log _{10} 5.0 \mathrm{cfu} \mathrm{g}^{-1}\right)\right.$ after 4 days of ambient storage with Bacillus, Clostridium, Staphylococcus sp and Aspergillus flavus being dominant microorganisms isolated. Whereas the fresh meat of L. libycus treated with $5 \% \mathrm{w} / \mathrm{v} \mathrm{NaCl}$ and stored at low temperatures $\left(4,-7^{\circ} \mathrm{C}\right)$ exhibited drastic reduction in microbial load with shelf-life extension to 6 days, that stored at $28^{\circ} \mathrm{C}$ preserved the meat for 4 days.

Keywords: Freshwater snail, brine, microbial quality, drying, shelf life, storage temperature. 
(Ezeama, 2004; Ekanem et.al 1994). However, the effects of the use of brine treatment, sun-drying, oven-drying or combination of these under different storage conditions have not been documented.

The objective of the work therefore, was to assess the effect of using brine treatment in combination with sun-drying, or oven-drying on the microbial quality of $L$. libycus meat stored at ambient temperatures. Microbial profile of traditionally dried samples of the meat as well as the effect of different storage temperatures on the microbial load of fresh or brined treated samples of the meat were also investigated.

\section{MATERIALS AND METHODS: Collection and processing of samples}

Fresh freshwater snails (Lanistes libycus) were collected from harvesters in Akaeze, Ebonyi State. The shells were surface sterilized ( $70 \%$ ethanol), shucked and eviscerated aseptically using hand-glove (Troge Medical GMBH-D Hamburg, Germany). The meats were aseptically removed and pooled into samples of $500 \mathrm{~g}$ each into sterile beakers. Several sub-samples ( $25 \mathrm{~g}$ each) were kept in four sets. One set was dipped into brine solution $(5 \% \mathrm{w} / \mathrm{v} \mathrm{NaCl})$ for $5 \mathrm{~min}$ and drip-dried before either sun-drying or oven-drying. One sub-set of the treated sample was exposed under the sun intensity for 3 consecutive days while the other was placed in a single layer on a tray in a Gallenkamp oven 300 at $80{ }^{\circ} \mathrm{C}$ for $6 \mathrm{~h}$. One of the subsets was oven-dried while another one was sun-dried. After oven-drying, the meats were cooled to ambient temperature $\left(28 \pm 2{ }^{\circ} \mathrm{C}\right)$ and packaged in polyethylene bags. The untreated fresh samples served as control. The packaged samples $(25 \mathrm{~g}$ each) were stored at ambient temperature for analyses at 2-day intervals.

Similarly, traditionally smoked, sun-dried $L$. libycus meat samples (Fig. 1) used in the study were obtained on prior arrangement from randomly selected local processors at Akaeze, Unwana and Okposi which are important L. libycus producing areas of Upper Cross River basin of Nigeria. The samples were similarly packaged and stored at ambient temperature with microbiological analyses carried out initially (day 0) and at 2-day intervals for 6 days.

\section{Storage of sample at different temperatures}

One set of brine treated ( $25 \mathrm{~g}$ each) and another set of freshly (untreated) prepared samples (25g each) were packaged in sterile polyethylene bags $(1.5 \mu \mathrm{m})$ and stored at different temperature $(-7,4$, 28 and $35^{\circ} \mathrm{C}$ ) using deep freezer, refrigerator and incubator respectively. The samples were initially analyzed for microbiological quality and after $24 \mathrm{~h}$ of storage and subsequently at 2 days interval for 6 day.

\section{Microbiological analyses of samples}

Twenty-five grams $(25 \mathrm{~g}$ ) of either the treated or untreated meat sample were blended (Moulinex, Paris, France) in $225 \mathrm{ml}$ of sterile $0.1 \%$ (w/v) peptone water $(\mathrm{pH} 7.2 \pm 0.2)$ to obtain 1:10 dilution. Subsequent dilutions were prepared and total viable counts (TVCs) and coliform counts determined in duplicate using pour plate method on Tryptone Soy Agar (TSA) and MacConkey agar (MA) respectively and incubated at $35-37^{\circ} \mathrm{C}$ for $24-$ $48 \mathrm{~h}$ or on malt extract agar (MEA) at $28 \pm 2{ }^{\circ} \mathrm{C}$ for 3-5 days for fungal counts. The colonies that developed on the plates and which were within their suitable ranges of 25-250 (Speck, 1984) were counted and recorded as cfu $\mathrm{g}^{-1}$.

\section{Identification of Isolates}

Representative discrete colonies were purified by streaking on TSA or MEA plates. Other media such as MacConkey agar, Triple Sugar Iron agar, Simmon Citrate agar, Litmus milk, Mannitol salt agar, Bacillus cereus selective agar (Biotec, Laboratory Ltd. Suffolks, UK) were used for the identification of the isolates. Following various biochemical tests (oxidase, catalase, coagulase, indole, $\mathrm{H}_{2} \mathrm{~S}$ production, urease, MRVP and oxidative/ fermentative utilization of glucose, lactose, mannitol, arabinose, sucrose and maltose) and description 
(Sneath et.al, 1986; Krieg and Holt, 1984) the isolates were identified. Similarly, the fungal isolates were identified based on their cultural and morphological characteristics (Samson and van Reenen - Hoesktra, 1988).

\section{Statistical analysis}

The data obtained were statistically analysed using analysis of variance (ANOVA) to determine the mean difference based on least significant (LSD) at $\mathrm{p}=0.005$ (Snedecor and Cochran, 1980).

\section{RESULTS AND DISCUSSION}

The microbial counts of brine treated and untreated dried meat of $L$. libycus stored at ambient temperature are presented in Table 1 . There was a significant $(\mathrm{p}=0.05)$ decrease in total viable counts (TVC) when brine was combined with either ovendrying or sun-drying. Maximum positive impacts on the microbial quality of seafoods seemexerted with combined preservative treatments (Ezeama, 2004; Efiuvwevwere and Isaiah 1998). The significant (p $=0.05)$ decrease in (TVcs) when brine was combined with either oven-drying or sun-drying (Table I) clearly shows the synergistic effect of such treatment. The combined treatment was able to reduce the TVCs to acceptable level (ICMSF, 1986) with that of brined oven-dried sample being more pronounced $\left(\log _{10} 3.92 \mathrm{cfu} \mathrm{g}^{-1}\right)$ by day 4 . Sun-drying alone cannot effectively preserve the meat beyond 2 days. Furthermore, the low coliform counts observed $\left(<\log _{10} 2.0\right)$ (Table 1) following the combined treatment may be due to the susceptibility to heat and dry cure injury of the coliforms. This observation agrees with the findings of Kemp et.al 1980. In addition, there were no significant differences $(\mathrm{p}=0.05)$ in TVCs, fungal and coliform counts of the brined sun-dried sample and ovendried sample during the storage period (Table 1). This finding may be of interest to local processors of the meat who cannot afford modern oven and can therefore preserve the meat by using brine solution that is relatively cheap and then sun-dry.
The microbial qualities of traditionally dried samples of the meat are presented in Tables 2 and 3. The TVCs of all the dried samples by day 4 (Table 2) were above $\log _{10} 5.0$ (Speck, 1984) indicating questionable safety of the samples after 4 days of ambient storage. Furthermore, the lower and significantly different TVCs and fungal counts of Unwana sampling location from those of other locations may be due to the awareness of Unwana processors (being a Polytechnic town) on the need to maintain good sanitary standards including evisceration of the snail samples. The consistent isolation of Bacillus cereus and Clostridium perfringens from the locally processed dried samples (Table 3) may be attributed to their ability to survive adverse conditions including high temperature such as $60{ }^{\circ} \mathrm{C}$ and above (Setlow, 1994) during the hot smoking practice. It is also likely that hot - smoking and sun-drying may not have been adequate to eliminate these spore-formers. The results support the findings of Efivwevwere and Isaiah (1998) and Peck et.al (1995) on the inability of hot smoking or temperature of $75^{\circ} \mathrm{C}$ for $27 \mathrm{~min}$ having little destructive effect on spore-formers. The presence of Aspergillus flavus, Salmonella and Staphylococcus $s p$ in the samples indicate the level of contamination of the product since grossly contaminated products have been known to frequently contain these pathogens (Speck 1984; Harris et.al 1975).

Whereas storage of the fresh meat at 28 and $35{ }^{\circ} \mathrm{C}$ resulted in increased microbial load with time (Table 4), treatment of the meat with $5 \% \mathrm{w} / \mathrm{v} \mathrm{NaCl}$ before storage at 28 and $35^{\circ} \mathrm{C}$ (Table 5) showed reduction in microbial load and hence extended the shelf-life of the meat by 4 days when stored at 28 ${ }^{\circ} \mathrm{C}$. However, low temperature $\left(-7^{\circ} \mathrm{C}\right)$ combination with $5 \% \mathrm{w} / \mathrm{v} \mathrm{NaCl} \mathrm{resulted} \mathrm{in} \mathrm{lower} \mathrm{microbial} \mathrm{quality}$ and further shelf-life extension to 6 days. These shelf life extension may be as a result of the susceptibility of proteolytic, putrefactive and spore-forming bacteria to relatively low concentrations $(3-7 \% \mathrm{w} /$ 
$\mathrm{v} \mathrm{NaCl}$ ) as earlier reported by Einarsson and Lauzon, 1995; Ihekoronye and Ngoddy, 1985. It is therefore pertinent that local processors who cannot afford low temperature storage can preserve the snail meat samples at ambient temperature $\left(28 \pm 2{ }^{\circ} \mathrm{C}\right)$ for a minimum of 4 days following treatment with sodium chloride solution $(5 \% \mathrm{w} / \mathrm{v})$ that is cheap and relatively available.

\section{CONCLUSION:}

The results of the work have highlighted that combining brine $(5 \% \mathrm{w} / \mathrm{v} \mathrm{NaCl})$ with either sundrying or oven-drying reduces the microbial load of ambient stored L. libycus meat to microbiologically acceptable level with that of oven-dried combination being more pronounced. In absence of oven-drying facilities, brine treatment combined with sun-drying can be used to achieve the same result since no significant difference $(p=0.05)$ existed between them in microbial load reduction and shelf life extension of the meat by 4 days. However, treatment of fresh meat of L. libycus with $5 \% \mathrm{w} / \mathrm{v} \mathrm{NaCl}$ before storage at $28{ }^{\circ} \mathrm{C}$ reduced the microbial load of the meat and extended the shelf life by 4 days. This is of interest to local processors of the meat who cannot afford low temperature storage facilities in the tropics.

\section{REFERENCES}

Arene, F. O. I Ibanga, E. S. and Asor, J. E. (1999) Freshwater snail and Crab intermediate hosts of Paragonimus species in two rural communities in Cross River Basin, Nigeria. Global Journal of Pure and Applied Science 5(2): 184-187.

Efiuvwevwere, B. J. O. and Isaiah, A. U. (1998). Effect of hygienic handling in combination with potassium sorbate treatment and smoking on the microbial quality and shelf - life stability of Croaker (Micropogenias furnieri) Z. Lebensm Unters Forsh A. 207: 13-17.

Einersson, H and Lauzon, H. L. (1995) Biopreservation of brined shrimp (Pandalus borealis) by bacteriocin from Lactic acid bacteria. Applied Environmental Microbiology 61(2): 569676).

Ekanem, E. O., Adegoke, G. O. and Ossai, G. E.A., (1994) Bacteriological and organoleptic characteristics of dehydrated West African clam (Egeria radiata Lamarch) meat. Nigerian Food Journal 12:66-73.

Ezeama, C. F. (2000) Studies of the ecological parameters and microbiological characteristics of freshwater snail. (Pila ovata). PhD. Thesis University of Port Harcourt, Nigeria p159.

Ezeama, C. F. (2004) Microbiological characteristics and sensory attributes of potassium sorbate treated and untreated smoked freshwater snail (Lanistes libycus). Global Journal of Pure and Applied Sciences 10(3): 363-367).

Harris, N. D., Martin, S. R. and Ellias, L. (1975). Bacteriological quality of selected delicatessen foods. Journal of Milk Food Technology, 38: 759-764.

ICMSF (International Commission on Microbiological Specification of Foods) (1986). Microorganism in Foods 2. Sampling for microbiological analysis. Principles and Specific Applications. $2^{\text {nd }}$ edn. Blackwell Scientific Publication Oxford.

Ihekoronye, A. I. And Ngoddy, P. O. (1985) Integrated Food Science and Technology for Tropics. Macmillan Publishers, London p386.

Kemp, J. D., Abidoye, D. P. O., Langlois, B. E., Frankiri, J. B. and Fox, J. D. (1980) Effect of curing ingredients, skinning and boning on yield quality and microflora of country ham, Journal of Food Science 45:174-177. 
Krieg, N. R. and Holt, J. G. (1984) Bergey's Manual of Systematic Bacteriology Vol. I Williams and Wilkins, Baltimore.

Obureke, J. U., Arene, F. O. I., and Ufodike, E. B. E., (1987) Occurrence and habitat preference of freshwater snails of Rivers State Nigeria. Nigerian Journal of Fisheries and Hydrobiology, 2:39-43.

Peck, M., Lund, W., Fairbairn, D. A., Kaspersson, A. S. and Undeland, P. C. (1995) Effect of heat treatment on survival of, and growth from, spores of non-proteolytic Clostridium botulinum at refrigeration temperatures. Applied Environmental Microbiology 61(6): 1780 - 1785.

Samson, R. A. and van Reenen-Hoekstra, E. S. (1988) Introduction of Foodborne Fungi. $3^{\text {rd }}$ edn. Central bureau Voor Schimmecultures. Baarn. The Netherlands.
Setlow, P. (1994) Mechanisms which contribute to the long-term survival of spores of Bacillus spp. Journal of Bacteriology Symposium Supplement. 76:495-601.

Snedecor, G. W. and Cochran, W. G. (1980)

Statistical Methods. $7^{\text {th }}$ edn. Iowa State University Press, Ames IA, U.S.A.

Sneath, H. P. A., Nair, N. S., Sharp, M. E. and Holt, J. G. (1986) Bergey's Manual of Systematic Bacteriology, Vol. 2. Williams and Wilkins, Baltimore, U.S.A.

Speck, M. L. (1984) Compendium of Methods for the Microbiological Examination of Foods $2^{\text {nd }}$ edn. American Public Health Association, Washington D.C., U.S.A. 


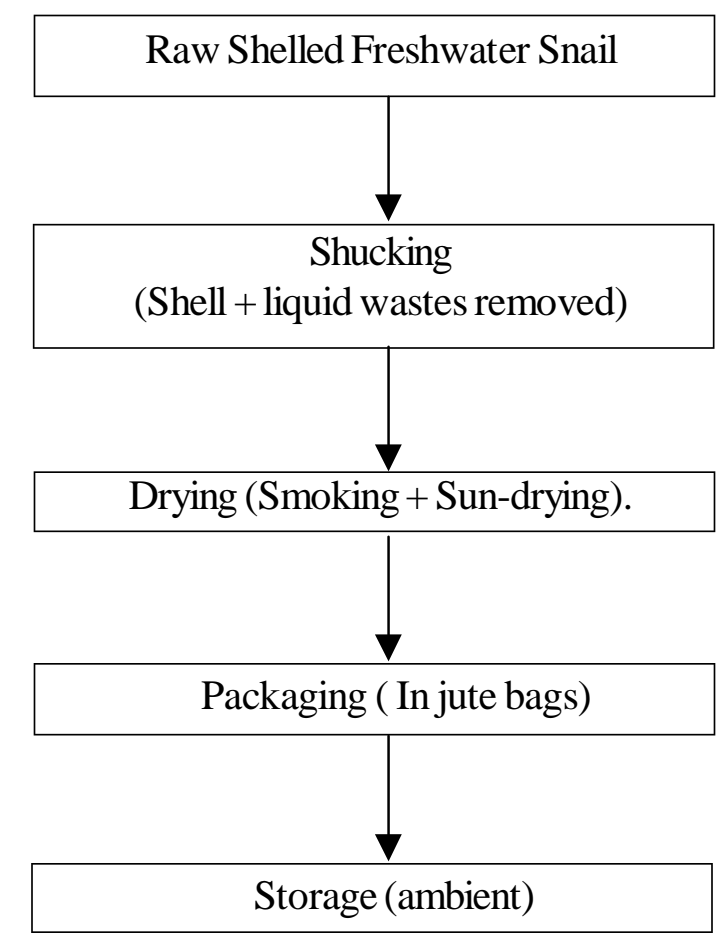

Fig 1 :Flowchart of traditional processing of freshwater snail(Lanistes libycus). 


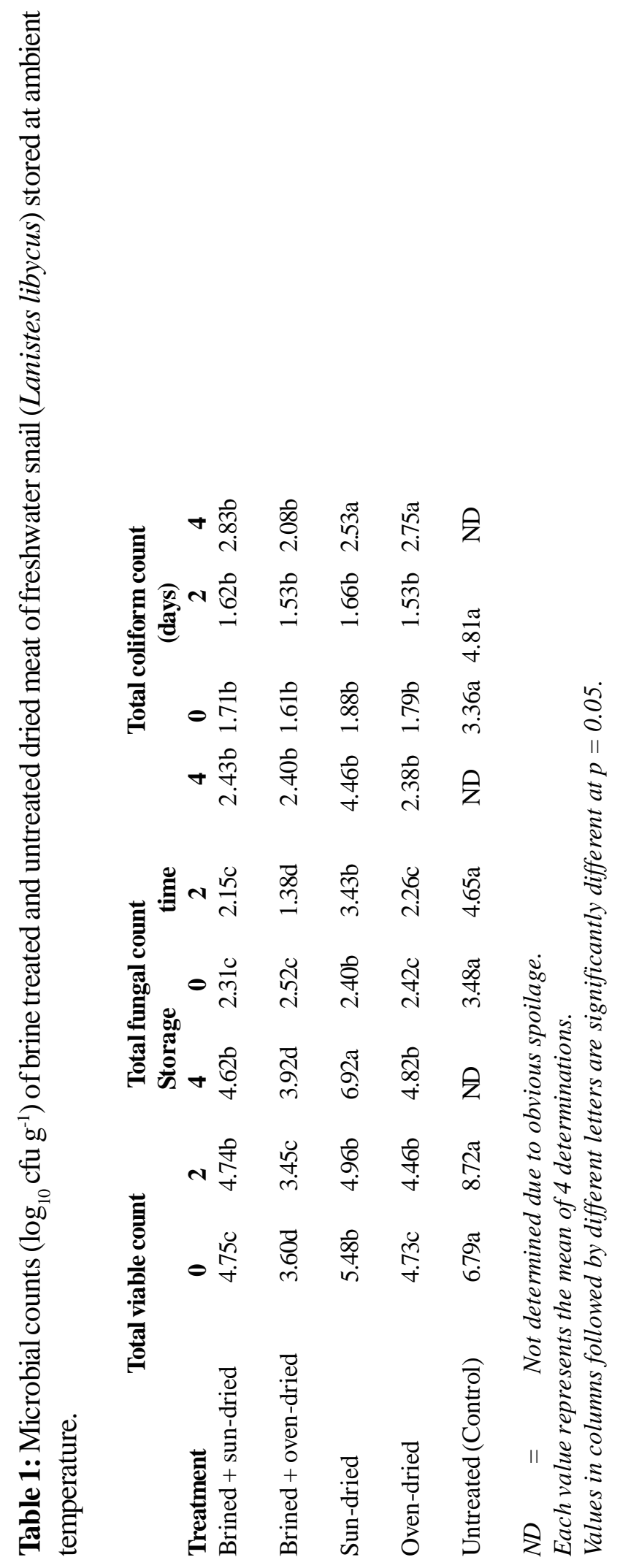




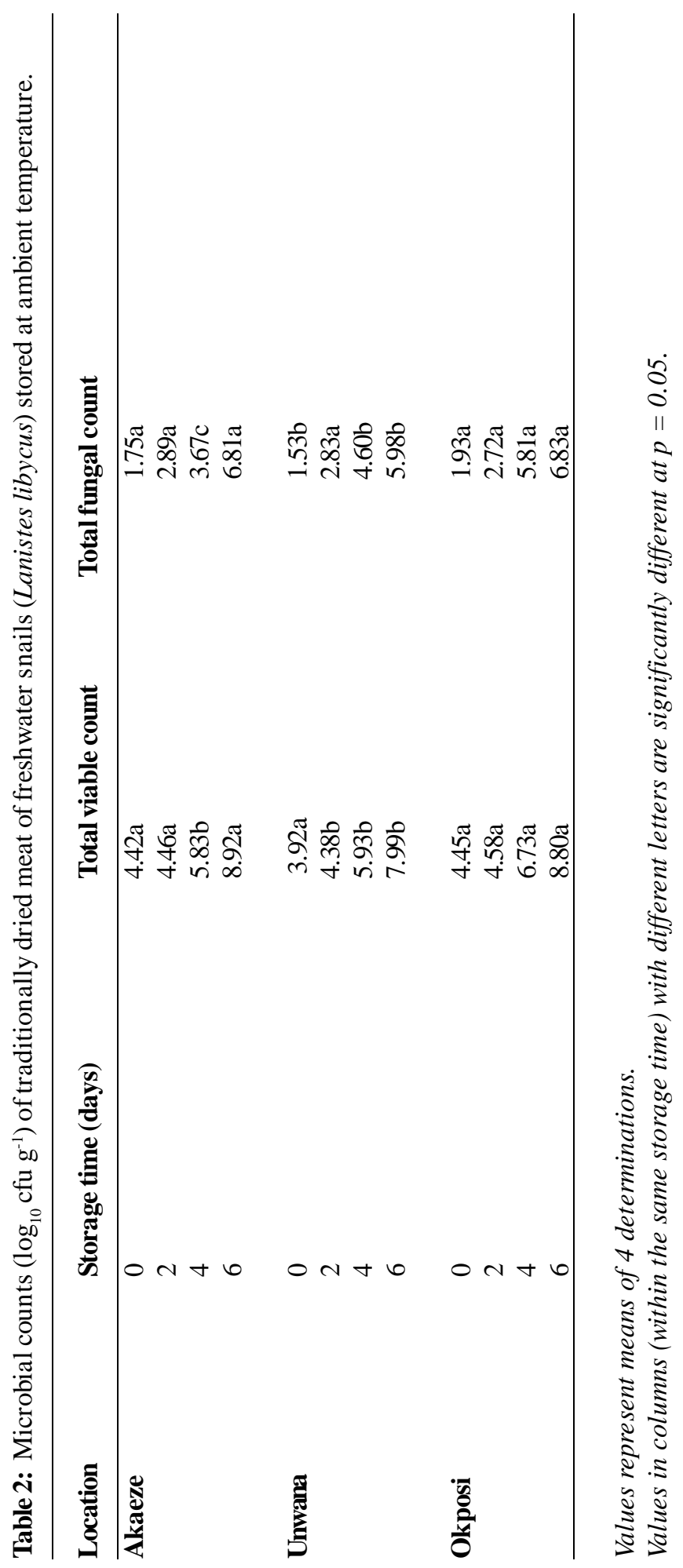




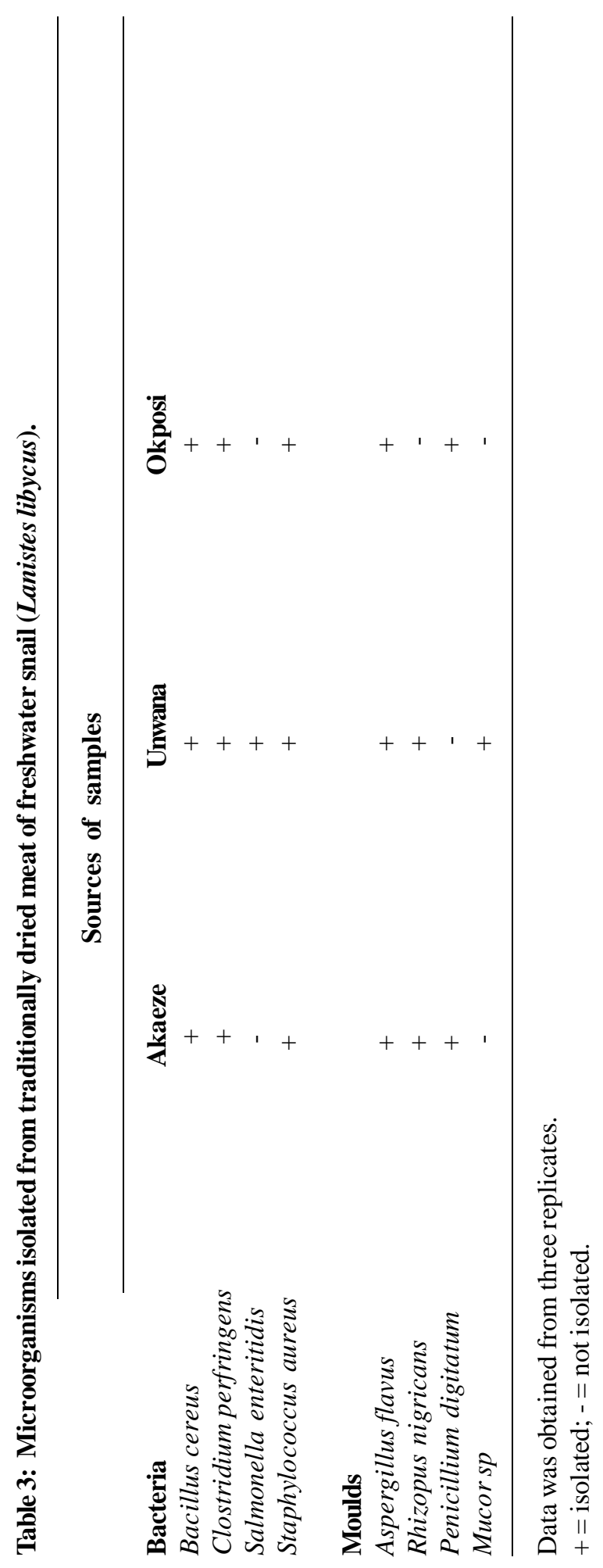




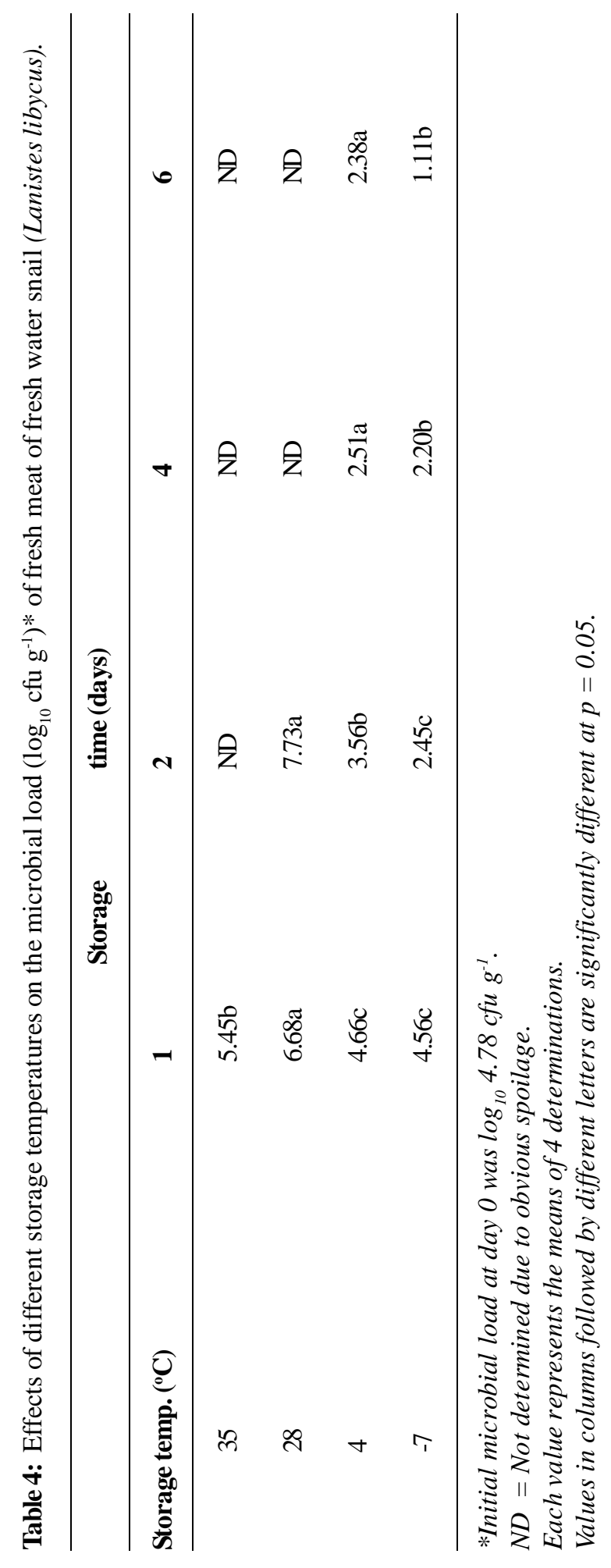




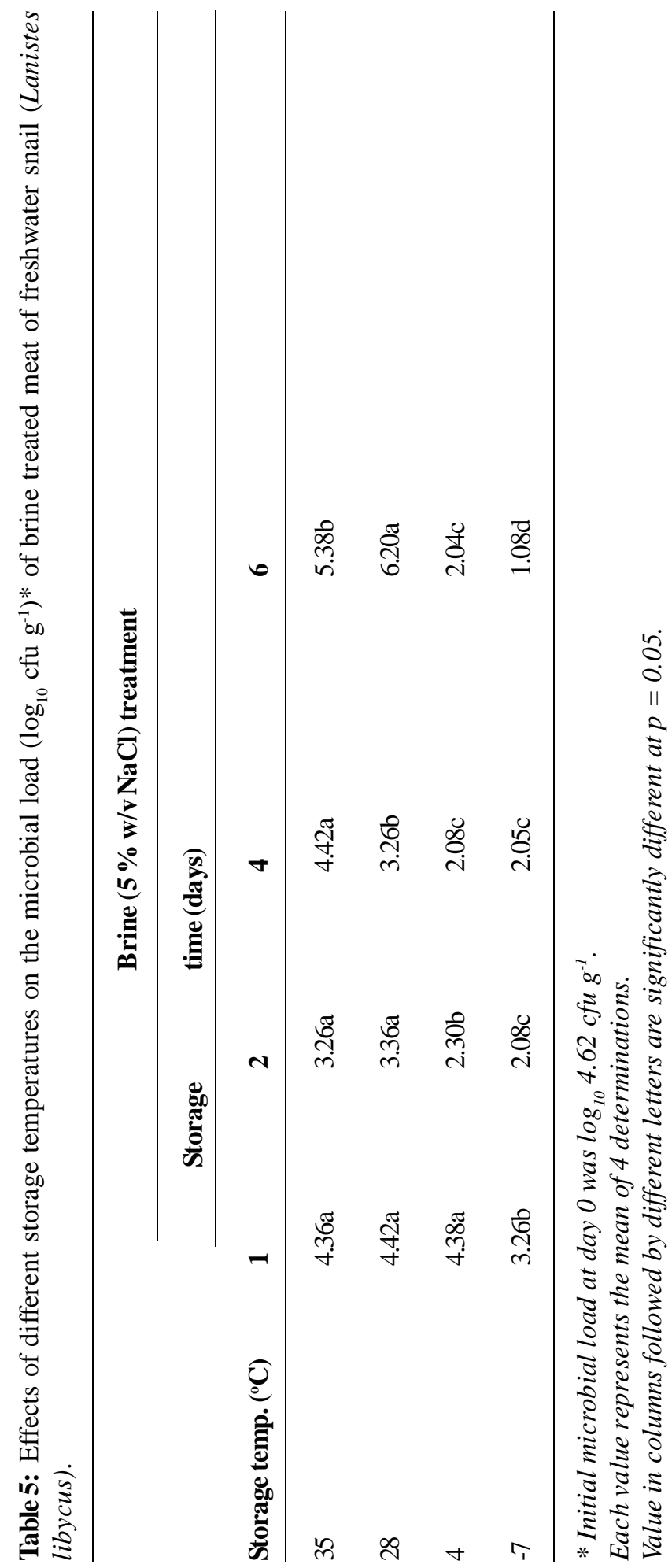

